\title{
Liability Exposure Effects on Earnings Conservatism: the Case of Cross-Listed Firms*
}

\author{
Carel Huijgen ${ }^{\dagger}$ and Martien Lubberink ${ }^{\ddagger}$ \\ JEL classification: G14, G38, M41
}

Keywords: Financial Reporting, Capital Markets, Earnings Conservatism.

Comments Welcome. Please do not quote or circulate without permission.

Current version: September 2001

\footnotetext{
*This paper has benefited from comments from Wendy Beekes and Auke Plantinga.

†University of Groningen, Faculty of Economics, Groningen, The Netherlands: c.a.huijgen@eco.rug.nl

¥The Management School, Lancaster University, Lancaster, UK: m.lubberink@lancaster.ac.uk
} 


\begin{abstract}
In this study we investigate earnings conservatism of cross-listed and domestically listed companies. We expect that conservatism will be more pronounced for cross-listed companies because they face the threat of litigation from a wider audience of shareholders than companies with a domestic listing only. Specifically, we compare conservatism of Dutch firms with a listing in the US to conservatism of Dutch firms without a US listing. The motivation to investigate this specific setting is that the liability exposure of managers and auditors in the US market is considered as far more burdensome than in the Dutch market.
\end{abstract}

Another interesting issue is that firms with a cross-listing in the US have to comply with different reporting standards; in our case Dutch GAAP and US GAAP. Therefore we not only compare conservatism of Dutch GAAP earnings of cross-listed companies versus that of domestically listed companies, but also conservatism of US GAAP earnings versus their Dutch GAAP counterparts. It is difficult to predict the outcomes of the latter question. One the one hand, if company managers view US GAAP earnings as especially important for US shareholders and Dutch GAAP earnings as especially relevant for Dutch shareholders they may try to apply conservatism accordingly. On the other hand, it can be argued that cross-listed companies cater to their US investors by presenting more conservative Dutch GAAP earnings numbers, so that it is not necessary to make US GAAP earnings incrementally conservative.

Empirical findings for the period from 1993 to 2000 show that Dutch GAAP earnings of cross-listed firms are significantly more conservative than earnings reported by firms with a domestic listing only. Maybe surprizing is the outcome that US GAAP earnings numbers reported by crosslisted companies are slightly less conservative than their Dutch GAAP counterparts, although the difference is not significant. This may imply that company managers view the Dutch GAAP earnings information as especially relevant in communicating with their shareholders irrespective of their origin. Further, the results seem to suggest that managers more or less mechanistically apply financial reporting requirements of foreign regulators. 


\section{Liability Exposure Effects on Earnings Conservatism: the Case of Cross-Listed Firms}

\section{Introduction}

In this study we investigate earnings conservatism - the extent to which the accounting system recognizes bad news regarding future cash flows more timely than good news - of cross-listed and domestically listed companies. We predict that conservatism will be more distinct for cross-listed companies because the managers of cross-listed companies and their auditors face the threat of litigation from a wider audience of shareholders compared to companies with a domestic listing only. Specifically, we compare conservatism of Dutch firms with a listing in the US to conservatism of Dutch firms without a US listing.

The motivation to investigate this specific setting is that the liability exposure of managers and auditors in the US market is considered as far more burdensome than in the Dutch market. Ball et al. (2000) argue that earnings conservatism will increase in the expected costs to auditors and managers from securities litigation: "securities lawsuits induce a demand for conservatism because the payoff function is asymmetric: they almost invariably allege investor losses arising from insufficiently conservative disclosures". In the US, legal liability exposure concerning reporting is viewed to be a serious issue. This is documented by, for example, Kothari et al. (1988), Skinner (1994), Dechow et al. (1996), and Basu (1997). In the Netherlands, however, legal liability exposure is preceived to be relatively low as suggested by Klaassen (1991), Bouma and Feenstra (1997), and Buijink and Eken (1999), amongst others.

An interesting issue that motivates our study is that firms with a cross-listing in the US have to comply with different reporting standards; in our case Dutch GAAP and US GAAP, the last one in the form of 20F filings required by the SEC. It is thus possible to compare conservatism not only between Dutch GAAP earnings of cross-listed companies and (Dutch GAAP) earnings of domestically listed companies, but also between US GAAP earnings and their Dutch GAAP counterparts of cross-listed companies. For the latter analysis it is difficult to predict what the outcomes will be. On the one hand, it can be argued that US GAAP earnings are incrementally conservative to Dutch GAAP earnings because of systematic differences between US and Dutch accounting standards which may affect reported conservatism. Moreover, if company managers view US GAAP earnings as especially important for US shareholders and Dutch GAAP earnings as especially relevant for Dutch shareholders they may try to set the level of conservatism accordingly. These considerations might lead us to expect differences between Dutch GAAP and US GAAP earnings conservatism. On the other hand, one might argue that if cross-listed companies already take care of 
conservatism in Dutch GAAP earnings numbers there is no need to make US GAAP earnings incrementally conservative. Further evidence in support of this perception is that Dutch and US GAAP accounting figures are easily available to both US and Dutch shareholders.

Empirical findings for the period from 1993 to 2000 show that the earnings of US listed firms reported according to Dutch GAAP are significantly more conservative than earnings reported by firms with a domestic listing. Surprizingly, however, is the evidence that US GAAP earnings numbers reported by cross-listed companies are slightly less conservative than their Dutch GAAP counterparts, although the difference is not significant. The outcomes may imply that company managers view their domestic (i.e. Dutch GAAP) earnings information as especially relevant in communicating with their shareholders irrespective of their origin. Further, the results seem to suggest that managers more or less mechanistically apply the financial reporting standards of foreign regulators in order to comply with their requirements.

This paper proceeds as follows. Section 2 describes the institutional financial reporting environment in the Netherlands and in the US and the effect they might have on earnings conservatism. In section 3 we discuss issues concerning cross listings and the accompanying reporting requirements. In section 4 we explain our methodology for measuring earnings conservatism. Section 5 describes the sample selection procedures and provides an overview of our data sources. Section 6 presents the empirical results. Finally, section 7 concludes.

\section{Reporting environment in the Netherlands and in the US}

In this section, we will give a global description of the institutional arrangements in the Netherlands and the US in order to clarify their influence on the reporting behavior of Dutch companies both cross- and domestically listed. We will especially focus on differences the accounting standards enforcement system and the related liability exposure between both countries, since these may ultimately affect the degree of conservatism in reported earnings numbers (Basu, 1997; Ball et., 2000). This section ends with the hypotheses about the reported conservatism of cross-listed versus that of non cross-listed firms.

\section{The Netherlands}

Financial reporting in the Netherlands is primarily governed by law. The first modern companies legislation in the Netherlands was approved in the beginning of the seventies as a result of political agitation behind the movement to democratize 
enterprise for the primary benefit of employees. It should be noticed that before the seventies, company law contained almost no reporting requirements. Later on, in 1983, the Dutch legislation was adapted to the Fourth and Seventh EEC Directives and transformed into Book 2 of the Civil Code. This book presents a more elaborate set of financial reporting requirements, which are applicable to all Dutch firms. The overriding principle of the modern legislation is the requirement that financial statements "shall give, in accordance with norms that are acceptable in the economic and social climate, an insight such that a wellfounded opinion can be formed concerning the financial position and income, and, in sofar as the nature of financial statements allow, concerning the solvency and the liquidity of the legal entity". When interpreting this provision, one should recognize that, in the Dutch cultural climate, stewardship reporting to long-term shareholders occupies a more important position than an orientation to buyers and sellers of securities. The Dutch legislators did not choose to specify detailed accounting methods in the legislation. Comparability is not even alluded to in Dutch companies legislation.

Together with the appearance of the modern companies legislation in 1970, two separate bodies were established: an advisory body taking inventory of valuation principles used in the "economic and social climate" as well as judging their acceptability and a judicial body securing compliance with the financial reporting provisions.

The first body, the Tripartite Study Group, later transformed into the Council on Annual Reporting, is a private sector reporting standards body and derives its mandate, support, and funds from the government. The Council plays a complementary and important role in the development of Dutch financial reporting standard setting. The Council members consist of delegations from employers, auditors and users of financial statements. The wide membership of the Council, representing a variety of stakeholders in Dutch financial reporting, is intended to give it external legitimacy and authority. The Council advises on financial reporting issues by way of publishing guidelines. These guidelines, however, are generally compromises between the different stakeholders represented by the Council. A consequence of this approach is that the guidance is characterized by ambivalence and a lack of clear directions for improvements. Furthermore, companies are able to deviate from the guidelines without appropriate disclosure of justification in the financial statements (Zeff et al., 1992).

The second body, the Enterprise Chamber, a branch of the Court of Justice at Amsterdam, has the exclusive jurisdiction over all judicial proceedings brought against companies on the ground that their financial statements have deviated from the law. It acts only when shareholders and other "interested parties" bring cases or when the Attorney-General attached to the Court of Justice can prove 
public interest in a proceeding initiated by his office. The Enterprise Chamber follows the Dutch law in financial reporting, and although the judges examine the relevant guidelines of the Council, they do not refer to them in their verdicts. Thus, the guidelines of the Council are not enforceable, which is detrimental for the authority of the Council.

Furthermore, the Dutch companies legislation contains a rule affecting the authority of the Enterprise Chamber as well. It requires that financial statements give a faithful representation of the income and financial position of the reporting company. In cases where rule-following would prevent firms from giving a faithful representation, the law requires that firms give at least sufficient information to allow inference of their income and financial position. This is the overriding principle of "insight", and the law assigns a higher priority to this than to rule-following (Schoonderbeek, 1997). In several judicial cases firms' managers successfully appealed the insight principle to justify their reporting behavior, which must have been frustrating to plaintiffs, and in the end to the Court as well.

The subjective interpretation of the principle of insight and the otherwise ambivalent financial reporting norms did have had an adverse effect on the effectiveness of the Enterprise Chamber. The first case brought to the Enterprise Chamber was only in 1977. During the eighties the number of proceedings increased, especially by the activities of a social pressure group concerned with the quality of company financial reporting. In the nineties, however, the number of new cases declined to a trickle and the Attorney General has not succeeded in demonstrating a public interest in his attempts at initiating judicial proceedings. Shareholders find the process costly and it can take from two to four years until a decision is announced. Klaassen (1991) describes the procedures of the Court as "too cumbersome, too much time-consuming and too costly". Perhaps the word "disappointing" best characterizes the functioning of the Enterprise Chamber's verdicts in financial reporting cases. Recently, the president of the Enterprise Chamber complained about his job by saying that "it has been extremely silent regarding financial reporting issues ${ }^{1} "$.

Alltogether, the Dutch institutional system, characterized by an overriding impact of the principle of insight, a marginally functioning Enterprise Chamber, as well as only voluntary guidelines issued by the Council on Annual Reporting, makes that Dutch companies ultimately enjoy a great deal of flexibility in the way they report their financial information which does not really provide incentives for managers to report earnings in a conservative way ${ }^{2}$.

\footnotetext{
${ }^{1}$ Het Financieele Dagblad, 23 April 2001.

${ }^{2}$ In the next few years we might expect a substantial reduction in the Dutch flexibility as the European Commission proposed to make the International Accounting Standards obligatory for listed companies in member states from 2005 onwards.
} 


\section{United States}

In the early 1930s, the US Congress passed the Securities Act of 1933 and the Security Exchange Act of 1934, the latter creating the Securities and Exchange Commission (SEC). The first law introduces a system of mandatory affirmative disclosure to prospective investors concerning securities offered for sale. The second law established a continuous disclosure system applicable to securities listed on national securities exchanges. Those enactments represented the first effective regulation of financial reporting. During its nearly 70 years of operation, the SEC has been a rigorous regulator of the US securities market. It has been especially vigilant concerning firms' financial disclosures. In the area of accounting principles, the SEC relies primarily on the standards of the Financial Accounting Standards Board (FASB) and its predecessors by stating upon the establishment of the FASB that "principles, standards and practices promulgated by the FASB in its Statements and Interpretations will be considered as having substantial authoritative support, and those contrary to such FASB promulgations will be considered to have no such support ${ }^{3 "}$. From the beginning, the SEC has operated on the premise that a narrower range of permitted practice is to be preferred over a broader range of alternatives. Comparability has always been important for the SEC, and it has believed that the fewest number of alternatives, together with a specification of how accounting principles are to be applied in the financial statements, is the best approach to promoting comparability. The SEC believes that financial statements reflecting material departures from GAAP are inherently misleading, and any such departures from GAAP must be rectified or explained before the corporation can remain in good standing with the Commission. Unless the departure is removed, with the corresponding change made in the company's financial statements, the SEC can issue an order that trading in the corporation's securities is suspended, or that the corporation may not issue securities, penalties that few companies would consider as comfortable.

How severe the consequences of an official investigation of the SEC can be is shown by Feroz et al. (1991) and Dechow et al. (1996). On the day of the announcement of alleged earnings manipulations companies suffered a price decline of about 9 percent $^{4}$. In almost all cases firms were accused of overstating earnings. Furthermore, Francis et al. (1993) provide evidence of a sample of companies that were target of earnings-related shareholder lawsuits. Most of these companies showed a stock price decline during the period over which damages were claimed. Thus, large stock price declines that accompany information releases generate higher expected legal costs than large stock price increases. This

\footnotetext{
${ }^{3}$ Statement of Policy on the Establishment and Improvement of Accounting Principles and Standards, Accounting Series Release no. 150, 20 December 1973.

${ }^{4}$ If the SEC informs the company of a formal investigation, then the firm is required to disclose this to shareholders, according to Act Release no. 5092.
} 
led Skinner (1993) to conclude that early disclosure of bad news is probably the best alternative to minimize the possibility of shareholder suits. In a related issue, Kothari et al. (1989) discuss several ways of reducing a company's auditor legal liability - for which it is likely that the corporate management bears some of the costs - including the option of reducing the level of accruals by becoming more conservative. And indeed, Basu (1997) shows increasing earnings conservatism during periods of heightening auditor liability exposure over the time period from 1963 to 1990 .

To conclude, it is much easier to penalize companies for earnings manipulation - especially earnings overstatement - in the US than in the Netherlands, firstly because the rules in the US specify a narrow range of permitted practices while Dutch accounting legislation leaves room for a considerable degree of flexibility, and secondly because the SEC may start investigations on its own while in the Netherlands merely the court is authorized to judge of a company's accounting practices only after complaints of direct stakeholders in the company. Illustrative for the differences in legal liability exposure between the Netherlands and the US are the examples of Philips Electronics and Baan Company - two Dutch companies with a US listing - where US shareholders in particular started lawsuits against the companies' executives, while Dutch shareholders remained silent at the time ${ }^{5}$.

\section{Hypotheses}

Due to the apparent differences in liability exposure embedded in the reporting environments of the Netherlands versus that of the US, we predict that the level of earnings conservatism will depend on a company's listing status. More precisely, we formulate the first hypothesis as:

Hypothesis 1: Dutch GAAP reported earnings of Dutch companies with a listing in the US are more conservative than reported earnings of Dutch companies without a US listing.

In comparing conservatism of US GAAP earnings versus that of Dutch GAAP earnings of US listed firms, the way of how managers think about their relative importance will be decisive. If company managers view US GAAP earnings as especially important for US shareholders and Dutch GAAP earnings as especially relevant for Dutch shareholders they may try to apply conservatism accordingly. Otherwise, if cross-listed companies already care for conservatism in Dutch earnings numbers there is no need to make the US GAAP earnings incrementally

\footnotetext{
${ }^{5}$ In the Philips case after untimely reporting of disappointing earnings (Financieele Dagblad, 7 September 1990) and in the Baan case for reasons of alleged mismanagment (Financieele Dagblad, 19 October 1999).
} 
conservative. This is motivated by the fact that US and Dutch accounting figures are easily available to both US and Dutch shareholders. Nevertheless, we formulate our second hypothesis in a positive way just as hypothesis 1:

Hypothesis 2: US GAAP reported earnings of Dutch companies with a listing in the US are more conservative than their Dutch GAAP counterparts.

\section{Cross listings and reporting requirements}

In the academic literature several arguments are made for a company to choose for a foreign listing in addition to a listing in its domestic country. The most classical motivation is that foreign listings lead to a lower cost of capital because they help overcome the segmentation of the local equity market (Roell, 1995). Firms obtain a broader investor base that accepts a lower rate of return by diversifying firm specific and country specific risks, which may be priced in a small market. Crosslisting may also be driven by marketing purposes, namely to increase visibility with customers by broadening product identification (Saudagaran and Biddle, 1991), easier financing of foreign acquisitions especially if such acquisition are paid by shares, and maintenance of labor relations in foreign countries by introducing share and option bonus plans for foreign employees which reduces transaction costs for them. The last motivation was explicitly stated by Royal Ahold - with more than half of the employees in the US - when it applied for a US listing and by Philips Electronics in going to the Tokyo Stock Exchange in order to recruit qualified personnel in Japan (Perotti and Cordfunke, 1998).

Typical for the Netherlands is the situation that the total number of domestic listings is rather low and that the market value of companies is asymmetrically distributed. That is: a handful of very large companies represents a substantial proportion of the total market capitalization of the Amsterdam Exchanges. Moreover, several Dutch companies do not have a competitive counterpart listed on the domestic exchange. A particular argument put forward by such companies - which we learned from interviewing representatives of these firms - to be listed abroad is that they want to be benchmarked within a global playing level field. Illustrative for this motivation is that the five Dutch companies, which have the longest track record of being listed in the US - Royal Dutch Petroleum, Unilever, Royal Dutch Airlines, Oce van der Grinten, and Philips Electronics - have no serious competitor in the Dutch market. This argument may be equally true for the recent interest of technology firms to move to the Nasdaq.

There are however also disadvantages in deciding to choose for a foreign listing. These have to do with increased pressure on executives due to closer public scrutiny, increasing reporting and disclosure requirements, additional listing fees and - especially relevant for our study - increasing liability exposure. 
The reporting requirements for foreign companies to file for a quotation on the US Stock Exchanges depend on the type of listing. In case of a level 1 American Depositary Receipt (ADR), which is traded over the counter, there are no additional reporting requirements above the existing regulations in the home country. With respect to levels 2 and 3 ADR's or the more direct New York Registered Shares, companies have to comply to the SEC requirements by means of $20-\mathrm{F}$ annual reports and $6-\mathrm{K}$ interim reports. A Form $6-\mathrm{K}$, comparable with a Form 8-K for US companies, is a document which has to be published in case of disclosure of relevant information, for example the quarterly report. Included in the $20 \mathrm{~F}$ report is the so-called reconciliation statement if the home financial statements are not made up according to US GAAP.

Global differences between Dutch GAAP en US GAAP are the rather flexible accounting standards in the Netherlands versus far stricter accounting standards in the US on the one hand, and more extensive disclosure requirements of the SEC on the other hand. To give examples of the latter: Dutch listed companies do not have to publish quarterly reports and a cash flow statement is formally not required, although almost all Dutch listed companies provide it voluntarily. With respect to differences in accounting standards the most pronounced items are summarized in table 1. Vergooosen (1996) inspected the US GAAP reconciliation statements in the 20F reports of Dutch US listed companies and found that these items were mentioned relatively often. Striking from table 1 is the flexibility that Dutch accounting standards provide to companies in making accounting choices.

[here table 1]

Especially relevant for this study is what the effects of different accounting standards will be on reported earnings conservatism. As we are interested in the asymmetric timeliness of recognizing bad and good news in earnings, we may compare phrases with respect to this issue in accounting standards or concepts. The FASB states in Statement of Accounting Concept 5: "In assessing the prospect that as yet uncompleted transactions will be concluded successfully, a degree of skepticism is often warranted. Moreover, as a reaction to uncertainty, more stringent requirements historically have been imposed for recognizing revenues and gains than for recognizing expenses and losses, and those conservative reactions influence the guidance for applying the recognition criteria to components of earnings".

The Dutch Law on Company Accounts discusses the principle of prudence in article 384 which is translated as: "In applying accounting policies prudence has to be taken care of. Profits are only recognized if they are realized on the date of making up the balance sheet. Losses and risks, which have their origin 
before the end of the fiscal year, have to be taken into account if the are known before compiling the financial statements". Moreover, the EEC 4th Directive, which is incorporated in the Law of Company Accounts describes prudence as: "Valuation must be made on a prudent basis, and in particular only profits made at the balance sheet may be included, account must be taken of all foreseeable liabilities and potential losses".

More concrete examples of earnings conservatism inherent in accounting standards - affecting both the income statement and the balance sheet - are asset impairment rules and lower of cost or market accounting for inventories which are present both in US and in Dutch accounting standards.

From the standards alone, it is thus difficult or even impossible to make predictions about whether US or Dutch accounting standards do influence the degree of earnings conservatism in practice most. Moreover, studying variation in accounting standards is not always useful as much accounting practice is not determined by accounting standards alone. Reporting outcomes are largely dependent on a multiple of estimates, which are not addressed by standards in detail, standards lag innovations in practice, and companies do not invariably implement standards (Ball et al., 2000).

If conservatism is defined more broadly as the preference for accounting policies that lead to lower reported values for shareholders' equity and earnings which is achieved by reporting the lowest values of assets and revenues and the highest values of liabilities and expenses (Belkaoui, 1985), we may get some idea of the differences between Dutch and US regulations by comparing equity book values and earnings for the US listed firms in our sample based on the 20F reconciliations. In figure 1 we depict the median of US GAAP earnings and equity book values as a fraction of Dutch GAAP earnings and equity book values over the period from 1993 to 2000. This fraction or ratio is comparable with the one Gray and Weetman (1991) used for comparing conservatism between different countries.

[here figure 1]

Figure 1 shows that US GAAP earnings are generally more conservative on the one hand - which is represented by the ratio having a value lower than one - while US GAAP equity book values are less conservative. The main reason for these deviations is the different treatment of purchased goodwill. In the US, goodwill has to be capitalized and amortized over a period of a maximum of 40 years. In the Netherlands purchased goodwill may be directly written off from equity reserves which was common practice until recently. This accounting 
treatment of goodwill causes relatively low book values of equity and relatively high earnings numbers - not depressed by goodwill amortisation charges - in times of frequent acquisitions. Figure 1 also shows that earnings differences are decreasing over time with the ratio moving from 0.79 in 1993 to 1.02 in 2000, while the gap between equity book values is prolonged and even widens from 1.18 in 1993 to 1.23 in 2000. We cannot provide an explanation for the different paths of convergence of earnings and equity book values ${ }^{6}$.

\section{Research methodology}

The methodology of measuring earnings conservatism corresponds to that of Basu (1997), Pope and Walker (1999) and Ball et al. (2000) but our return specification is innovative. The methodology assumes that accounting earnings reflect prior firm value changes asymmetrically. Negative value changes - bad news - will be more promptly recognized in earnings while positive value changes - good news - will be picked up by earnings more gradually.

A model that relates reported earnings to value changes can be specified as follows (Pope and Walker, 1999):

$$
\frac{Y_{t}}{P_{t-1}}=\frac{1}{\kappa} \frac{P_{t}}{P_{t-1}}-\frac{\varphi_{t} \Delta \eta_{t}^{+}}{P_{t-1}}+\frac{v_{t} \Delta \eta_{t}^{-}}{P_{t-1}}+\frac{\eta_{t}}{P_{t-1}}
$$

The earnings innovation in this model can be split into a good news component: $\Delta \eta_{t}^{+}\left(\Delta \eta_{t}=\Delta \eta_{t}^{+}>0\right)$; a bad news component: $\Delta \eta_{t}^{-}\left(\Delta \eta_{t}=\Delta \eta_{t}^{-}<0\right)$; and a variable $\left(\eta_{t}\right)$ representing the effects of prior period news on current reported earnings: $\eta_{t}=f\left(\Delta \eta_{t-1}, \Delta \eta_{t-2}, \ldots, \Delta \eta_{t-\infty}\right)$. This model shows that reported earnings $\left(Y_{t}\right)$ do not perfectly reflect value changes. Parameter $\varphi_{t}$ defines the under-recognition of good news in earnings $\left(\Delta \eta_{t}^{+}>0, \Delta \eta_{t}^{-}=0\right)$. Parameter $v_{t}$ defines the prompt recognition of bad news in earnings $\left(\Delta \eta_{t}^{+}=0, \Delta \eta_{t}^{-}<0\right)$, which reflects the idea that reported earnings reflect unfavorable news more quickly. Conservative accounting results in positive values for both $\varphi_{t}$ and $v_{t}$.

We introduce a dummy (News) for bad news firms in order to estimate separate coefficients for two firm groups: bad news firms and good news firms. Bad news firms are those with a negative market adjusted performance during period $t$. The use of the dummy allows us to rewrite equation (1) as:

\footnotetext{
${ }^{6}$ One reason we put forward is that the US listed companies in our sample recently adopted the recommendation of the Council of Annual Accounts (Autumn 2000) to capitalize purchased goodwill without doing this retroactively. The expected effect is that Dutch GAAP earnings will converge to US GAAP earnings while there remains a lag between Dutch GAAP and US GAAP equity book value.
} 


$$
\frac{Y_{t}}{P_{t-1}}=\frac{1}{\kappa}+\frac{1-\varphi_{t}}{\kappa} R_{t}+\frac{\varphi_{t}+v_{t}}{\kappa} N e w s \cdot R_{t}+\frac{\eta_{t}}{P_{t-1}}
$$

This model underlies Basu (1997) and Ball et al. (2000), who use the following regression equation:

$$
\frac{Y_{t}}{P_{t-1}}=\beta_{0}+\beta_{1} N e w s+\beta_{2} R_{t}+\beta_{3} N e w s \cdot R_{t}+\varepsilon_{t}
$$

The slope coefficients of regression equation (3) measure the responsiveness of reported earnings to the news captured in prior returns. The slope coefficients, therefore, can be denoted as return response coefficients (RRC 's).

Empirical comparisons of conservatism require a comparison of the slope value for good news $\left(\beta_{2}\right)$ versus the slope coefficient of bad news $\left(\beta_{2}+\beta_{3}\right)$. Due to conservatism, the good news slope value $\left(\beta_{2}\right)$ is lower than the bad news slope coefficient $\left(\beta_{2}+\beta_{3}\right)$. The steeper slope indicates that reported earnings $(Y)$ reflect returns $(R)$ more timely when firms face unfavorable future prospects, and less timely when they face favorable prospects. The larger the dispersion between the slope values, the more conservative reported earnings are. We use a conservatism measure $(C M)$ that standardizes the bad news slope value by the good news slope value:

$$
C M=\frac{\beta_{2}+\beta_{3}}{\beta_{2}}=\frac{1+v_{t}}{1-\varphi_{t}}
$$

Conservative earnings result in $C M$ values larger than 1: bad news earnings are more responsive to returns than are good news earnings.

Our method of measuring returns is innovative. Existing research on conservatism uses a fixed return period of a year that is independent of the earnings announcement date. We, however, assume that managers react to prior returns until a (couple of) week(s) before the actual earnings announcement. Moreover, using announcement dates will lead to a more precise measurement of the relation between earnings and returns. Our return period starts 7 days before the announcement date of previous year's earnings and ends 7 days before the date of announcing current year's earnings. The motivation to include the market reaction on previous earnings is that managers may evaluate prior year's market reaction in deciding which earnings number to report in the current year. The reason to exclude the market reaction on current year's earnings announcement is that we are interested in the way how current year's earnings picks up good and bad news which is coherent with using reversed regressions. Including the date 
of announcement in the return period would turn the assumed causality around. We then would combine a reversed regression with an event study.

For measuring good and bad news, we used market adjusted returns. Market adjusted returns were defined as the difference in the buy and hold returns of the company minus the buy and hold returns of the Amsterdam Exchanges (AEX) or Amsterdam Midkap Exchanges (AMX) market index, dependent on its presence in one or the other. Below we discuss to including only companies which make up the composition of the AEX and the AMX in our sample. The procedure thus implicitly uses size adjusted returns.

\section{Sample selection and data description}

Our sample of Dutch companies contains US listed companies which are included in the current composition of the AEX and AMX indices for the period from 1993 to 2000. The AEX is a weighted index covering those 25 companies which have the largest market capitalization and trading volume during the most recent year. The AMX contains the next 25 companies based on size and trading volume criteria. Both indices are reshuffled yearly ${ }^{7}$.

The US listed companies are compared with all other companies covering the AEX and AMX indices in order to match for size as far as possible. This match for size is, however, imperfect since most US listed companies are included in the largest capitalizations based AEX index, while most non US listing make up the second-largest capitalizations based AMX index. We will perform some tests for size later on in order to examine whether the outcomes are possibly driven by an underlying size effect. Table 2 details the US listed companies, together with the particular US Stock Exchange on which they are quoted and the time period covered in our sample versus the matched sample of non US listed companies. Also stated in table 2 is the presence of our sample firms in the FTSE Europe Top 100 and the S\&P Europe 350.

[here table 2]

One of the underlying assumptions in testing differences in conservatism between Dutch US listed and non US listed firms is that US shareholders will own shares of US listing more frequently than non US listings. While the fact that a firm chooses to be listed in the US in order to attract US shareholders stands on its own, the most direct evidence would be a country-based segmentation of

\footnotetext{
${ }^{7}$ Only three Dutch companies with a US listing - Arcadis, Docdata and Alpha Toolex - are not included in our sample due to their absence in both indices.
} 
shareholders for each sample firm but these figures are not available. A more indirect approach is to study whether our sample firms are included in well-known European Stock Indices that are especially relevant to (passive) index investors. Table 2 shows that from the US listings 9 out of 16 firms are present in the FTSE Europe Top 100, while only 1 out of 27 firms from the non US listings is included. For the S\&P Europe 350, the frequencies are 12 out of 16 US listings and 10 out of 27 non US listings. It seems therefore reasonable to expect that the US listings in our sample are more popular under US shareholders than the non US listings

As can be seen in table 2, not all companies in our sample have a US listing for the whole period of investigation. The question is what to do with the firmyear US listing observations before the US listing start date. We chose to exclude them from our sample instead of including them in the matching sample of non US listed companies since it is may be possible that companies that intend to going listed abroad already anticipate this decision in their reporting behavior. Further, we only include companies which have a listing history of more than 2 years.

It is not feasible to match for industries, since some US listed companies do not have equal counterparts of non US listings as can be seen, for example, from the companies Dutch Royal Airlines, Royal Dutch Petroleum and the telecom company KPN. However, if we inspect the industry descriptives of the firm-year observations in table 3 , there does not seem to be a substantial industry bias. All industries covering more than 10 percent of the firm/year observations in the one sample are also represented in the other sample - although with a lesser weight - with the exception of the electronic machinery sector which covers 15 percent of the US listing sample. Moreover, Giner and Rees (2001) and Lubberink and Huijgen (2001) test for earnings conservatism differences between industries and fail to give meaningful results.

[here table 3]

Dutch GAAP accounting data were extracted from the Yearbook of Dutch Companies, while the US GAAP reconciliations were hand-collected either from the annual reports if disclosed, or from the Form 20F Reports. Price, return and market adjusted return data were obtained from Thompson Financial Datastream. Earnings announcement dates were gathered from "Het Financieele Dagblad", the leading Dutch newspaper with respect to financial issues and from the AEX news web-site.

In handling with outlier observation variables we followed the following procedure. We winsorized the return values exceeding 100 percent. We viewed this 
to be a logical choice since negative returns are naturally restricted to minus 100 percent. Winsoring was applied for two reasons. First, it minimizes deletion of precious observations. Second, outlier observations based on data trimming were mostly caused by excessive return values, in an individual case exceeding 500 percent. We report results according to the winsorized data procedure although the outcomes obtained with other procedures were qualitatively equal ${ }^{8}$.

\section{Results}

This section presents empirical results. Table 4 shows descriptives of the different samples we use for testing the relationship between earnings conservatism and cross-listings. Table 5 reports earnings conservatism for the whole sample while table 6 shows conservatism results for different subsamples. Tables 7 and 8 present test results which investigate the robustness of the results in table 6 . In table 9 , we investigate whether the results are possibly driven by size.

In table 4, we display sample characteristics containing the mean, median, variance and minimum and maximum values of the variables. Panel A covers the whole sample, panel B the US listed firms with both their Dutch and US GAAP key accounting figures and panel $\mathrm{C}$ the non US listed firms. A couple of things are noteworthy in table 4 .

[here table 4]

First, there are almost no differences between the subsamples with respect to their median (market adjusted) returns. This precludes the explanation that the degree of conservatism is merely an expression of poor performance. Second, the mean (market adjusted) returns of both subsamples are substantially higher than their median values. These differences are driven by a small group of observations - especially those in the information technology - performing exceptional well in the last few years of our period of investigation. As noted earlier in the text, we winsorized these extreme observations to a maximum return value of $100 \%$. Third, the mean and median values of the market capitalization of the US listed firms exceeds those of the non US listed firm by a factor of about eight. It seems therefore necessary to study whether this size difference has any influence on the regression outcomes. Fourth, if we compare the earnings to price and book to market ratios based on Dutch GAAP versus US GAAP, we see that applying Dutch GAAP leads to a higher Earnings to Price ratio, while applying US GAAP produces the highest Market to Book ratio although the differences in

\footnotetext{
${ }^{8}$ Trimming the variables exceeding three times the standard deviation from the mean and recognizing no outliers at all.
} 
the Earnings to Price ratio are relatively small. This result is directly related to our earlier observation that US GAAP earnings are generally lower and US GAAP equity book values higher than their Dutch counterparts which is depicted in figure 1. Fifth, the difference in median return on equity according to US GAAP versus Dutch GAAP is striking due to an opposite numerator and denominator effect of earnings and equity book values.

Table 5 presents the outcomes of the basic earnings to price regressions for the entire pooled cross-section and time-series sample. Panel A shows the results of the symmetric regression without considering any earnings conservatism, where the slope coefficient $\left(\beta_{2}\right)$ represents the return response coefficient. As expected, the return response coefficient is positive and significant, but its value of 0.05 is rather low as compared to other European countries reported by Giner and Rees (2001). In panel B we include the incremental bad news variable for measuring the asymmetric relation between earnings and returns which is represented by coefficient $\left(\beta_{3}\right)$. In our empirical regression estimation, we leave out the news dummy variable as defined in equation (3). In that model, the coefficient of the news dummy variable $\left(\beta_{1}\right)$ has an expected value of zero which makes this dummy variable rather superfluous in empirical regressions. Essentially, earnings conservatism is captured by the interaction variable measured as return multiplied by the news dummy and the correspondent $\left(\beta_{3}\right)$ coefficient. Panel B of table 5 shows that earnings reported by Dutch companies are conservative indeed but the degree of conservatism - as indicated by the conservatism measure $(C M)$ having a value of 2.13 - is rather moderate compared to conservatism in other countries (Ball et al., 2000; Giner and Rees, 2001).

\section{[here table 5]}

In table 6 , we show results which are directly concerned with our hypotheses. The panels A, B and C present earnings conservatism for (Dutch GAAP) earnings of non US listed firms, Dutch GAAP earnings of US listed firms and US GAAP earnings of US listed firms respectively. From these subsamples only Dutch GAAP earnings of US listed firm show the conservatism coefficient $\left(\beta_{3}\right)$ to be significantly positive while in the other subsamples the coefficient $\left(\beta_{3}\right)$ is insignificantly different from zero. These differences in conservatism are also indicated by the respective CMs of the subsamples. The CM is highest for the Dutch GAAP earnings of US listed firms (3.99), followed by US GAAP earnings of US listed firms (2.16) and the (Dutch GAAP) earnings of non US listed firms (1.58). In the sample of US listed firms, the symmetric return response coefficient $\left(\beta_{2}\right)$ is not significant anymore, both for their Dutch GAAP earnings and their US GAAP earnings. These results can be interpreted as follows. On the one hand, they seem confirm our first hypothesis that US listed firms are more likely to 
report bad news earlier than good news than non US listed firms. On the other hand, they do not support our second hypothesis that US GAAP earnings are additionally conservative to Dutch GAAP earnings of US listed firms.

[here table 6]

As table 6 uses regressions performed on separate subsamples, we cannot make inferences whether the conservatism coefficients of the subsamples differ from each other in a statistical sense. In order to resolve this issue, we ran regressions for our whole sample of firms in which we introduce an additional dummy (Cross) to distinguish firms that are listed in the US from those that are not. The results of this extended model are tabulated in table 7 . In panel A, Dutch GAAP earnings of US listed firms are included while in panel B, we use their US GAAP earnings. Panel A of table 7 shows that the incremental bad news coefficient for Dutch GAAP earnings of US listed firms $\left(\beta_{5}\right)$ is positive $(0.09)$ and significant ( $p$-value of 0.03 ). The incremental bad news coefficient for all firms $\left(\beta_{3}\right)$ does not significantly differ from zero. Furthermore, the value of the CM of US listed increases to 57.48 although it is strongly inflated by a low denominator value. Panel B, however, does not show a significant incremental conservatism of US GAAP earnings of US listed firms above that of (Dutch GAAP) earnings of non US listings.

[here table 7]

Although the results in table 6 and table 7 more or less suggest that US GAAP earnings do not show incremental conservatism to their Dutch GAAP counterparts, we did not directly compare them so far. In order to formally test hypothesis 2, we ran an additional regression for the US listed firms in which we defined the dependent earnings variable as the difference between US GAAP and Dutch GAAP earnings for one and the same firm. This variable was used in the symmetric earnings return model and in the asymmetric earnings return model.

Table 8, panel A, shows that the US GAAP and Dutch GAAP earnings difference does not have any significant relationship with returns. Adding the conservatism variable does not improve the results while the coefficient $\left(\beta_{3}\right)$ takes on a negative sign. In other words, the Form $20 \mathrm{~F}$ reconciliations do not add any incremental conservatism to Dutch reported earnings, which comes down to the rejection of hypothesis 2 . These outcomes may imply that company managers view their domestic GAAP earnings as especially relevant in communicating with their shareholders irrespective of their origin and that the reporting requirements 
of foreign regulators are seen as only a process of mechanistically applying foreign accounting standards in calculating foreign GAAP earnings. This interpretation is supported by the fact that US GAAP numbers are normally disclosed with a time lag of several weeks after the announcements of Dutch GAAP numbers. In one case we learned from a company's representative that the disclosure of Form $20 \mathrm{~F}$ reconciliations was postponed until a few days before the required date of filing the numbers with the SEC, which is six months after the end of the fiscal year. In other words, managers do not seem to acknowledge the disclosure of $20 \mathrm{~F}$ reports as very important in the sense of timely reporting these figures compared to the financial statements based on local standards.

\section{[here table 8]}

As we noted earlier, size is strongly correlated to listing status. It is therefore necessary to investigate whether differences in earnings conservatism are possibly explained by size. Table 9 shows results of regressions where size, measured as the natural logarithm of market value has any relationship with conservatism.

[here table 9]

In panel A we added the size variable multiplied by the bad news dummy in the basic regression. The bad news interaction coefficient $\left(\beta_{3}\right)$ remains significantly positive while the coefficient of the variable representing size $\left(\beta_{6}\right)$ is negative but insignificant. In panel B we included size in the extended regression model and again the coefficient of the size variable $\left(\beta_{6}\right)$ is insignificantly different from zero. The coefficient $\left(\beta_{4}\right)$ measuring the incremental conservatism of US listed firms is positive (0.09) and significant ( $p$-value of 0.02 ). This evidence precludes size as an underlying variable explaining a higher level of earnings conservatism of US listed firms as compared to that of non US listed firms.

\section{Conclusions}

Existing literature on conservatism has demonstrated that differences in earnings conservatism are mainly the result of differences in institutional factors. Basu (1997) for example, shows that liability exposure of auditors and managers for tardy disclosure of unfavorable news explains earnings conservatism. Ball et al. (2000) and Giner and Rees (2001) demonstrate that the political influence on financial reporting is related to earnings conservatism, which comes down to a country-based explanation of differences in conservatism. They show that earnings reported in common law countries are more conservative than earnings reported under a codified law regime. 
We add to this field of research by investigation cross-sectional differences in earnings conservatism. More specific, we study whether conservatism of Dutch companies with a US listing is more pronounced than that of companies which are merely quoted on the Dutch Stock Exchange. The idea is that managers of cross-listed companies and their auditors face the threat of litigation or a formal investigation into misleading financial statements from a wider audience compared to companies with a domestic listing only. The underlying assumption is that there are institutional differences in the enforcement of practices to comply with accounting standards. Comparing the Dutch regulatory institutions with those in the US, we see wide differences in the ways companies are subject to liability exposure with respect to their financial statements. Penalizing companies for earnings manipulation, especially earnings overstatement, seems to be much easier in the US than in the Netherlands for several reasons. First, the rules in the US specify a narrow range of permitted practices while Dutch accounting legislation leaves room for a considerable degree of flexibility which makes it more difficult for a plaintiff to demonstrate earnings manipulation. Second, the SEC may start investigations on its own, while in the Netherlands the only way of alleging misleading reporting is to go to court which is perceived as cumbersome, time-consuming and costly for the plaintiff. Empirical findings for the period from 1993 to 2000 indeed show that the earnings of US listed firms reported according to Dutch GAAP are significantly more conservative than (Dutch) GAAP earnings reported by firms with a domestic listing.

A further interesting issue is that US-listing have to meet different reporting standards which result in different earnings numbers, those which are based on Dutch GAAP versus those that are reported according to US GAAP. Comparing the conservatism of those alternative earnings figures does not suffer from an omitted variables problem since both subsamples are perfectly matched. We do not, however, find significant differences in conservatism between Dutch GAAP earnings and their US GAAP counterparts. The outcomes may imply that company managers view their domestic earnings information (Dutch GAAP) as especially relevant in communicating with their shareholders irrespective of their origin. That is: company managers already take care of conservatism in determining the accruals included in Dutch GAAP earnings. Calculating the earnings figures in accordance to US GAAP, as required in the reconciliation statement, is then a more or less mechanistical process of applying the financial reporting standards of foreign regulators without making them incrementally conservative. In support of this finding is the fact that US and Dutch GAAP earnings figures are easily available to both US and Dutch shareholders and that the Form 20F reports are normally disclosed with a substantial time lag after the announcement of Dutch GAAP numbers. 


\section{References}

Ball, R., S. P. Kothari, and A. Robin. 2000. The Effect of Institutional Factors on Properties of Accounting Earnings. Journal of Accounting and Economics 29 (1, September) 1-51.

Basu, S. 1997. The Conservatism Principle and the Asymmetric Timeliness of Earnings. Journal of Accounting and Economics 24 (1, December) 3-37.

Belkaoui, A. R., ed. 1985. Accounting Theory. London: Academic Press Ltd.

Bouma, J. L., and D. W. Feenstra. 1997. Accounting and Business Economics Traditions in the Netherlands. European Accounting Review 6 (2, June) 175-97.

Buijink, W. F. J., and R. Eken. 1999. The System for the Regulation of Financial Reporting in the Netherlands. In Accounting Regulation in Europe, ed. S. McLeay. Basingstoke: Macmillan.

Dechow, P. M., R. G. Sloan, and A. P. Sweeney. 1996. Causes and Consequences of Earnings Manipulation: An Analysis of Firms Subject to Enforcement Actions by the SEC. Contemporary Accounting Research 13 (1, Spring) 1-36.

Feroz, E. H., K. Park, and V. S. Pastena. 1991. The Financial and Market Effects of the SEC's Accounting and Auditing Enforcement Releases. Journal of Accounting Research 29 (supplement) 107-42.

Giner, B., and W. Rees. 2001. On the Asymmetric Recognition of Good and Bad News in France, Germany, and the UK. Forthcoming Journal of Business Finance and Accounting

Klaassen, J. 1991. Jaarverslaggeving in Nederland. In FMA Kroniek, ed. J. P. C. M. Van den Hoeven, A. De Bos, and C. D. Knoops, 69-75. Groningen: Wolter-Noordhoff.

Kothari, S. P., T. Lys, C. W. Smith, and R. L. Watts. 1989. Auditor Liability and Information Disclosure. Journal of Accounting, Auditing $\&$ Finance 4 307-39.

Lubberink, M. J. P., and C. A. Huijgen. 2001. A Wealth-Based Explanation for Earnings Conservatism. Forhtcoming European Finance Review

Perotti, E. C., and E. Cordfunke. 1998. Do Foreign Cross-Listings Increase Firm Value: Evidence from Announcement Effects of Dutch Firms. Maandblad voor Accountancy en Bedrijfseconomie 11 (November) 570-78. 
Pope, P. F., and M. Walker. 1999. International Differences in the Timeliness, Conservatism and Classification of Earnings. Journal of Accounting Research 36 (Supplement) 53-100.

Roell, A. 1995. The Decision to Go Public: an Overview. LSE Financial Group Discussion Paper no 225.

Saudagaran, S. M., and G. C. Biddle. 1995. Foreign Listing Location: a Study of MNS's and Stock Exchanges in Eight Countries. Journal of International Business Studies 319-41.

Schoonderbeek, W. J. 1997. Algemene Grondslagen van de Jaarrekening in de Wet- en Regelgeving. In Externe Verslaggeving in Theorie en Praktijk, ed. M. N. Hoogendoorn, J. Klaassen, and F. Krens, 150-68. Vol. 1. Den Haag: Delwel.

Skinner, D. J. 1994. Why Firms Voluntarily Disclose Bad News. Journal of Accounting Research 32 (1, Spring) 38-60.

Vergoossen, R. G. A. 1996. Invloed Beursnotering in Verenigde Staten op Stelselkeuze en Additionele Informatieverschaffing. Maandblad voor Accountancy en Bedrijfseconomie 11 (November) 597-608.

Weetman, P., and S. J. Gray. 1991. A Comparative International Analysis of the Impact of Accounting Principles on Profits: the USA versus the UK, Sweden, and the Netherlands. Accounting and Business Research 84 363-79.

White, H. 1980. A Heteroskedasticity-Consistent Covariance Matrix Estimator and a Direct Test for Heteroskedasticity. Econometrica 48 (May) 817- 38.

Zeff, S. A., F. van der Wel, and C. Camfferman. 1992. Company Financial Reporting, a historical and comparative study of the Dutch regulatory process. Amsterdam: Elsevier Science. 


\section{Tables}

Table 1:

Main differences between Dutch and US GAAP

\begin{tabular}{lll} 
Item & Dutch GAAP & US GAAP \\
\hline treatment of goodwill & write-off from equity allowed & capitalization required \\
amortization of intangibles & no amortization allowed & $\begin{array}{l}\text { systematic amortization } \\
\text { required }\end{array}$ \\
\begin{tabular}{lll} 
valuation of tangibles & replacement value allowed & historic cost required \\
treatment of interest costs of & capitalization allowed & capitalization required \\
tangibles in construction & market value allowed & market value required \\
valuation of short-term securities & based on current salaries & based on future salaries \\
valuation of pension liabilities & fixed & derived from market \\
discount rate of & & interest rate \\
pension liabilities & allowed at management's & allowed if decision \\
recognition of & intention & is irreversible \\
reorganization costs & classified as short-term & classified as equity \\
treatment of declared & liabilities & \\
dividends & & \\
\hline \hline
\end{tabular} & & \\
\hline
\end{tabular}


Table 2: Dutch Firms with a US listing

\begin{tabular}{lccccc} 
Firm Name & First Year & Last year & Listed on & Index & Obs \\
\hline abn amro holding*a $\left(7^{\mathrm{b}}\right)$ & 1996 & 2000 & NYSE & AEX & 5 \\
aegon* (5) & 1993 & 2000 & NYSE & AEX & 8 \\
akzo nobel (9) & 1993 & 1999 & Nasdaq & AEX & 7 \\
asm international & 1997 & 2000 & Nasdaq & MCap & 4 \\
asm lithography (12) & 1996 & 2000 & Nasdaq & AEX & 5 \\
besi & 1996 & 2000 & Nasdaq & MCap & 5 \\
elsevier* (10) & 1994 & 2000 & NYSE & AEX & 7 \\
gucci (16) & 1996 & 2000 & NYSE & AEX & 5 \\
ing* (2) & 1996 & 2000 & NYSE & AEX & 5 \\
klm & 1993 & 2000 & NYSE & MCap & 8 \\
oce & 1993 & 2000 & Nasdaq & MCap & 8 \\
philips electronics* (3) & 1993 & 2000 & NYSE & AEX & 8 \\
royal ahold* (6) & 1993 & 2000 & NYSE & AEX & 8 \\
royal dutch* (1) & 1993 & 2000 & NYSE & AEX & 8 \\
royal kpn* (18) & 1995 & 2000 & NYSE & AEX & 6 \\
unilever* (4) & 1993 & 2000 & NYSE & AEX & 8 \\
\hline
\end{tabular}

a FTSE Eurotop 100 constituents are denoted with a * (September 2001).

b Between brackets is the ranking of the firm's portfolio weight in the S\&P Europe 350 Index, on September, 2001. The ranking includes the Dutch firms of the S\&P 350 Europe Index only. 
Table continued: Dutch Firms without US Listing

\begin{tabular}{lcccc} 
Firm Name & First Year & Last year & Index & Observations \\
\hline amstelland & 1993 & 2000 & MCap & 8 \\
buhrmann $\left(22^{\mathrm{a}}\right)$ & 1993 & 2000 & AEX & 8 \\
cmg & 1996 & 2000 & MCap & 5 \\
csm & 1993 & 2000 & MCap & 8 \\
draka & 1993 & 2000 & MCap & 8 \\
dsm (17) & 1993 & 2000 & AEX & 8 \\
fortis*b (8) & 1993 & 2000 & AEX & 8 \\
getronics (21) & 1993 & 2000 & AEX & 8 \\
hagemeyer (19) & 1993 & 2000 & AEX & 8 \\
heineken (11) & 1993 & 2000 & AEX & 8 \\
hoogovens / corus & 1993 & 1998 & MCap & 6 \\
hunter douglas & 1993 & 2000 & MCap & 8 \\
ihc caland & 1993 & 2000 & MCap & 8 \\
laurus & 1993 & 2000 & MCap & 8 \\
nedlloyd & 1993 & 2000 & MCap & 8 \\
nutreco & 1998 & 2000 & MCap & 3 \\
ordina & 1993 & 2000 & MCap & 8 \\
pakhoed / vopak & 1993 & 2000 & MCap & 8 \\
randstad (20) & 1993 & 2000 & MCap & 8 \\
royal numico (15) & 1993 & 2000 & AEX & 8 \\
royal wessanen & 1993 & 2000 & MCap & 8 \\
van der moolen & 1993 & 2000 & MCap & 8 \\
van ommeren & 1993 & 1998 & MCap & 6 \\
vedior & 1998 & 2000 & MCap & 3 \\
vendex kbb & 1996 & 2000 & MCap & 5 \\
vnu (13) & 1993 & 2000 & AEX & 8 \\
wolters kluwer (14) & 1993 & 2000 & AEX & 8 \\
\hline \hline
\end{tabular}

${ }^{\text {a }}$ FTSE Eurotop 100 constituents are denoted with a * (September 2001).

b Between brackets is the ranking of the firm's portfolio weight in the S\&P Europe 350 Index, on September, 2001. The ranking includes the Dutch firms of the S\&P 350 Europe Index only. 
Table 3: Industry Descriptives for Firm Groups

Panel A

Dutch Firms with a US listing

\begin{tabular}{lcc} 
Industry & NoFirms $^{\mathrm{a}}$ & Nobs $_{\text {Total }}^{\mathrm{b}}$ \\
\hline Oil and Gas & 1 & 0.08 \\
Publishing & 1 & 0.07 \\
Chemicals and Pharma & 1 & 0.07 \\
Food Products & 1 & 0.08 \\
Electrical Machinery & 2 & 0.15 \\
Retail Trade & 2 & 0.12 \\
Transportation & 1 & 0.08 \\
Telecom & 1 & 0.06 \\
Finance & 3 & 0.17 \\
Information Technology & 3 & 0.13 \\
\hline
\end{tabular}

Panel B

Dutch Firms without a US listing

\begin{tabular}{lcc} 
Industry & NoFirms & Nobs/Total \\
\hline Food Products & 5 & 0.18 \\
Paper Products & 1 & 0.04 \\
Publishing & 2 & 0.08 \\
Chemicals and Pharma & 1 & 0.04 \\
Steel & 1 & 0.03 \\
Metal Products & 2 & 0.08 \\
Building and Construction & 2 & 0.08 \\
Wholesale Trade & 1 & 0.04 \\
Retail Trade & 2 & 0.07 \\
Transportation & 3 & 0.11 \\
Finance & 2 & 0.08 \\
Information Technology & 3 & 0.11 \\
Business Services & 2 & 0.06 \\
\hline \hline a Number of firms & \multicolumn{2}{l}{} \\
b Number of firm-year observations as a fraction of total \\
$\quad$ (within each group).
\end{tabular}


Table 4: Descriptives of Variables

Panel A: Whole Sample ${ }^{\mathrm{a}}$

\begin{tabular}{lccccc} 
& mean & median & stdv & $\max$ & $\min$ \\
\hline Return $^{\mathrm{b}}$ & 0.33 & 0.23 & 0.60 & 5.67 & -0.83 \\
Market Adjusted Return $^{\mathrm{c}}$ & 0.11 & 0.04 & 0.57 & 5.64 & -0.81 \\
Market Value $^{\mathrm{d}}$ & 7.19 & 1.75 & 15.54 & 130.48 & 0.02 \\
$\mathrm{P} / \mathrm{B}^{\mathrm{e}}$ & 3.61 & 2.29 & 4.07 & 28.21 & 0.26 \\
$\mathrm{Y}(\mathrm{nl})^{\mathrm{f}}$ & 595 & 126 & 1545 & 13555 & -137 \\
$\mathrm{Y}(\mathrm{nl}) / \mathrm{P}^{\mathrm{g}}$ & 0.10 & 0.09 & 0.09 & 0.67 & -0.51 \\
$\mathrm{Y}(\mathrm{nl}) / \mathrm{B}(\mathrm{nl})^{\mathrm{h}}$ & 0.23 & 0.19 & 0.35 & 1.88 & -4.40 \\
Nobs $^{\mathrm{i}}$ & 301 & & & & \\
\hline
\end{tabular}

Panel B: Dutch Firms with a US listing

\begin{tabular}{lccccc} 
& mean & median & stdv & $\max$ & $\min$ \\
\hline Return & 0.35 & 0.22 & 0.74 & 5.67 & -0.83 \\
Market Adjusted Return & 0.13 & 0.05 & 0.72 & 5.64 & -0.81 \\
Market Value & 16.74 & 7.96 & 23.24 & 130.48 & 0.13 \\
$\mathrm{P} / \mathrm{B}(\mathrm{nl})$ & 2.89 & 2.11 & 2.76 & 15.65 & 0.43 \\
$\mathrm{Y}(\mathrm{nl})$ & 1400 & 595 & 2387 & 13555 & -95 \\
$\mathrm{Y}(\mathrm{nl}) / \mathrm{P}$ & 0.08 & 0.09 & 0.07 & 0.28 & -0.51 \\
$\mathrm{Y}(\mathrm{nl}) / \mathrm{B}$ & 0.14 & 0.15 & 0.46 & 0.62 & -4.40 \\
$\mathrm{P} / \mathrm{B}(\mathrm{us})^{\mathrm{j}}$ & 2.14 & 1.48 & 2.50 & 15.65 & 0.32 \\
$\mathrm{Y}(\mathrm{us})$ & 1386 & 406 & 2417 & 13555 & -423 \\
$\mathrm{Y}(\mathrm{us}) / \mathrm{P}$ & 0.08 & 0.08 & 0.08 & 0.28 & -0.51 \\
$\mathrm{Y}(\mathrm{us}) / \mathrm{B}(\mathrm{us})$ & 0.08 & 0.11 & 0.45 & 0.43 & -4.40 \\
$\mathrm{nobs}$ & 105 & & & & \\
\hline
\end{tabular}

a Descriptives of variables of Dutch listed firms over the period 1993-2000. Firms are the constituents of the main index (AEX) and of the MidCap index. Panel A presents descriptives of the whole sample. Panel B presents descriptives of cross listed frims only. Panel C presents descriptives of noncross listed firms only.

b Return: the raw buy and hold return over a window starting a week before last year's earnings announcement and ending a week before the current earnings announcement.

c Market Adjusted Return: The same return as (b) but now adjusted for the return on the appropriate index: either AEX or Midcap.

d Market Value: Market capitalisation, in billions of Euros.

e P/B: Market to book value of shareholder's equity.

f $\mathrm{Y}(\mathrm{nl})$ : Earnings before extraordinairy items, in millions of Euros.

g $\mathrm{Y}(\mathrm{nl}) / \mathrm{P}$ : Earnings over price at the end of the return window.

h $\mathrm{Y}(\mathrm{nl}) / \mathrm{B}$ : Earnings over Book value value of shareholder's equity.

i Nobs: number of observations.

j US counterparts of items f-h. 
Descriptives of Variables continued

Panel C: Dutch Firms without a US listing ${ }^{\mathrm{a}}$

\begin{tabular}{lccccc} 
Non Cross listed & mean & median & stdv & $\max$ & $\min$ \\
\hline Return & 0.32 & 0.24 & 0.52 & 3.12 & -0.78 \\
Market Adjusted Return & 0.10 & 0.04 & 0.48 & 3.04 & -0.73 \\
Market Value & 2.07 & 0.97 & 2.88 & 16.45 & 0.02 \\
$\mathrm{P} / \mathrm{B}(\mathrm{nl})$ & 4.00 & 2.43 & 4.58 & 28.21 & 0.26 \\
$\mathrm{Y}(\mathrm{nl})$ & 164 & 89 & 312 & 2768 & -137 \\
$\mathrm{Y}(\mathrm{nl}) / \mathrm{P}$ & 0.11 & 0.09 & 0.09 & 0.67 & -0.12 \\
$\mathrm{Y}(\mathrm{nl}) / \mathrm{B}(\mathrm{nl})$ & 0.28 & 0.21 & 0.25 & 1.88 & -0.23 \\
nobs & 196 & & & & \\
\hline \hline
\end{tabular}

${ }^{\text {a }}$ See previous page for explananation. 
Table 5: Earnings and Leading Returns Regressions

$$
\frac{Y}{P}=\beta_{0}+\beta_{2} \cdot R+\beta_{3} \cdot N e w s \cdot R+\varepsilon^{\mathrm{a}}
$$

Panel A: Symmetric Earnings to Price Relationship

\begin{tabular}{lccc} 
& $\beta_{0}$ & $\beta_{2}$ & $\beta_{3}$ \\
\hline$\beta$ & 0.09 & 0.05 & \\
$t^{\mathrm{b}}$ & 15.95 & 3.31 & \\
$\mathrm{p}^{\mathrm{c}}$ & 0.00 & 0.00 & \\
Nobs, Rsq $^{\mathrm{d}}$ & 301 & 0.05 & \\
\hline
\end{tabular}

Panel B: Asymmetric Earnings to Price Relationship

\begin{tabular}{lccc} 
& $\beta_{0}$ & $\beta_{2}$ & $\beta_{3}$ \\
\hline$\beta$ & 0.09 & 0.04 & 0.04 \\
$t^{\mathrm{b}}$ & 15.66 & 2.10 & 1.76 \\
$\mathrm{p}^{\mathrm{c}}$ & 0.00 & 0.02 & 0.04 \\
Nobs, Rsq, CM $^{\mathrm{d}}$ & 301 & 0.06 & $\mathbf{2 . 1 3}$ \\
\hline \hline
\end{tabular}

${ }^{a}$ Results are from pooled time-series and cross-sectional regressions of variables of Dutch listed firms over the period 1993-2000. Firms are the constituents of the main index (AEX) and of the MidCap index. Panel A presents the Earnings to Price relationship. Panel B presents results on the asymmetric relationship between earnings and leading returns: conservatism. Conservatism results in conservatism measure $(\mathrm{CM})$ values larger than $1 . Y$ is the earnings of fiscal year $t$ before extraordinary items. $P$ is the stock price at the start of the return window. $R$ is the raw buy and hold return over a window starting a week before last year's earnings announcement and ending a week before the current earnings announcement. Returns are Winsorized: values exceeding 1 are set to 1 . News is the news dummy variable for firms with negative market adjusted performance.

b,c White heteroskedasticity-consistent one-sided $t$-values, and associated pvalues

d Nobs: Number of observations, Rsq: R-squares adjusted for degrees of freedom. CM: Measure of conservatism $=\frac{\beta_{2}+\beta_{3}}{\beta_{2}}$ 
Table 6: Earnings and Leading Returns Regressions: Basic Model

$$
\frac{Y}{P}=\beta_{0}+\beta_{2} \cdot R+\beta_{3} \cdot N e w s \cdot R+\varepsilon^{\mathrm{a}}
$$

Panel A: Dutch Firms without a US listing

\begin{tabular}{lccc} 
& $\beta_{0}$ & $\beta_{2}$ & $\beta_{3}$ \\
\hline$\beta$ & 0.10 & 0.05 & 0.03 \\
t-value & 14.56 & 1.74 & 0.76 \\
p-value & 0.00 & 0.04 & 0.22 \\
Nobs, Rsq, Cm & 196 & 0.05 & $\mathbf{1 . 5 8}$ \\
\hline
\end{tabular}

Panel B: Dutch Firms with a US listing: Dutch GAAP

\begin{tabular}{lccc} 
& $\beta_{0}$ & $\beta_{2}$ & $\beta_{3}$ \\
\hline$\beta$ & 0.07 & 0.02 & 0.07 \\
t-value $^{\mathrm{b}}$ & 7.46 & 1.51 & 2.69 \\
p-value $^{\mathrm{c}}$ & 0.00 & 0.07 & 0.00 \\
Nobs, Rsq, Cm $^{\mathrm{d}}$ & 105 & 0.08 & $\mathbf{3 . 9 9}$ \\
\hline
\end{tabular}

Panel C: Dutch Firms with a US listing: US GAAP

\begin{tabular}{lccc} 
& $\beta_{0}$ & $\beta_{2}$ & $\beta_{3}$ \\
\hline$\beta$ & 0.07 & 0.02 & 0.02 \\
t-value $^{\mathrm{b}}$ & 6.65 & 1.19 & 0.46 \\
p-value $^{\mathrm{c}}$ & 0.00 & 0.12 & 0.32 \\
Nobs, Rsq, Cm $^{\mathrm{d}}$ & 105 & 0.02 & $\mathbf{2 . 1 6}$ \\
\hline \hline
\end{tabular}

${ }^{a}$ Results are from pooled time-series and cross-sectional regressions of variables of Dutch listed firms over the period 1993-2000. Firms are the constituents of the main index (AEX) and of the MidCap index. Panel A presents results on conservatism for non cross-listed firms. Panel B presents results on earnings conservatism for cross-listed firms. Earnings are Dutch GAAP earnings. Panel C presents results for cross-listed firms, where the earnings are restated into US GAAP. $Y$ is the earnings of fiscal year before extraordinary items. $P$ is the stock price at the start of the return window. $R$ is the raw buy and hold return over a window starting a week before last year's earnings announcement and ending a week before the current earnings announcement. Returns are Winsorized: values exceeding 1 are set to 1 . News is the news dummy variable for firms with negative market adjusted performance.

b,c White heteroskedasticity-consistent one-sided t-values and associated pvalues.

d Nobs: Number of observations, Rsq: R-squares adjusted for degrees of freedom. CM: Measure of conservatism $=\frac{\beta_{2}+\beta_{3}}{\beta_{2}}$. Conservatism results in conservatism measure $(\mathrm{CM})$ values larger than 1 . 
Table 7: Earnings and Leading Returns Regressions: Extended Model

$$
\frac{Y}{P}=\beta_{0}+\beta_{2} \cdot R+\beta_{3} \cdot N \text { ews } \cdot R+\beta_{4} \cdot \text { Cross } \cdot R+\beta_{5} \cdot N e w s \cdot \text { Cross } \cdot R+\varepsilon^{\mathrm{a}}
$$

Panel A: Dutch GAAP

\begin{tabular}{lccccc} 
& $\beta_{0}$ & $\beta_{2}$ & $\beta_{3}$ & $\beta_{4}$ & $\beta_{5}$ \\
\hline$\beta$ & 0.09 & 0.06 & 0.01 & -0.06 & 0.09 \\
t-value $^{\mathrm{b}}$ & 15.83 & 2.34 & 0.36 & -2.39 & 1.94 \\
p-value $^{\mathrm{c}}$ & 0.00 & 0.01 & 0.38 & 0.00 & 0.03 \\
Nobs, Rsq, CM & 301 & & 0.08 & & 57.48 \\
\hline
\end{tabular}

Panel B: US GAAP

\begin{tabular}{lccccc} 
& $\beta_{0}$ & $\beta_{2}$ & $\beta_{3}$ & $\beta_{4}$ & $\beta_{5}$ \\
\hline$\beta$ & 0.09 & 0.06 & 0.01 & -0.06 & 0.05 \\
t-value $^{\mathrm{b}}$ & 15.17 & 2.39 & 0.31 & -2.68 & 0.72 \\
p-value $^{\mathrm{c}}$ & 0.00 & 0.01 & 0.36 & 0.01 & 0.23 \\
Nobs, Rsq, CM & 301 & & 0.06 & & -12.64 \\
\hline \hline
\end{tabular}

${ }^{\text {a }}$ Results are from pooled time-series and cross-sectional regressions of variables of Dutch listed firms over the period 1993-2000. Firms are the constituents of the main index (AEX) and of the MidCap index. Panel A presents results on earnings conservatism, where earnings are Dutch GAAP earnings. Panel B presents results for cross listed firms, where the earnings are restated into US GAAP. $Y$ is the earnings of fiscal year before extraordinary items. $P$ is the stock price at the start of the return window. $R$ is the raw buy and hold return over a window starting a week before last year's earnings announcement and ending a week before the current earnings announcement. Returns are Winsorized: values exceeding 1 are set to 1 . News is the news dummy variable for firms with negative market adjusted performance. Cross is the dummy variable for cross listed firms.

b,c White heteroskedasticity-consistent one-sided t-values and associated p-values.

d Nobs: Number of observations, Rsq: R-squares adjusted for degrees of freedom. CM: Measure of conservatism $=\frac{\beta_{2}+\beta_{3}+\beta_{4}+\beta_{5}}{\beta_{2}+\beta_{4}}$. Conservatism results in conservatism measure $(\mathrm{CM})$ values larger than 1 . 
Table 8: Earnings differences and Leading Returns Regressions

$$
\frac{Y_{U S}-Y_{N L}}{P}=\beta_{0}+\beta_{2} \cdot R+\beta_{3} \cdot N e w s \cdot R+\varepsilon^{\mathrm{a}}
$$

Panel A: Symmetric Earnings to Price Relationship

\begin{tabular}{lccc} 
& $\beta_{0}$ & $\beta_{2}$ & $\beta_{3}$ \\
\hline$\beta$ & 0.00 & -0.01 & \\
$t^{\mathrm{b}}$ & 0.19 & -1.27 & \\
$\mathrm{p}^{\mathrm{c}}$ & 0.43 & 0.10 & \\
Nobs, Rsq $^{\mathrm{d}}$ & 105 & 0.03 & \\
\hline
\end{tabular}

Panel B: Asymmetric Earnings to Price Relationship

\begin{tabular}{lccc} 
& $\beta_{0}$ & $\beta_{2}$ & $\beta_{3}$ \\
\hline$\beta$ & -0.00 & -0.00 & -0.05 \\
$t^{\mathrm{b}}$ & -0.57 & -0.47 & -1.42 \\
$\mathrm{p}^{\mathrm{c}}$ & 0.28 & 0.32 & 0.08 \\
Nobs, Rsq, CM $^{\mathrm{d}}$ & 105 & 0.08 & \\
\hline
\end{tabular}

${ }^{\text {a }}$ Results are from pooled time-series and cross-sectional regressions of variables of Dutch listed firms over the period 1993-2000. The dependent variable is the difference between US GAAP Earnings $\left(Y_{U S}\right)$ and Dutch GAAP Earnings $\left(Y_{N L}\right)$. Firms are the constituents of the main index (AEX) and of the MidCap index. All firms are Dutch with a cross-listing on a US stock exchange. Panel A presents the Earnings differences to Price relationship. Panel B presents results on the asymmetric relationship between earnings differences and leading returns: conservatism. Conservatism results in conservatism measure $(\mathrm{CM})$ values larger than $1 . P$ is the stock price at the start of the return window. $R$ is the raw buy and hold return over a window starting a week before last year's earnings announcement and ending a week before the current earnings announcement. Returns are Winsorized: values exceeding 1 are set to 1 . News is the news dummy variable for firms with negative market adjusted performance.

b,c White heteroskedasticity-consistent one-sided $t$-values, and associated pvalues

d Nobs: Number of observations, Rsq: R-squares adjusted for degrees of freedom. CM: Measure of conservatism $=\frac{\beta_{2}+\beta_{3}}{\beta_{2}}$ 
Table 9: Earnings and Leading Returns Regressions

$$
\begin{aligned}
& \frac{Y}{P}=\beta_{0}+\beta_{2} \cdot R+\beta_{3} \cdot \text { News } \cdot R+\beta_{4} \cdot \text { Cross } \cdot R \\
& +\beta_{5} \cdot \text { News } \cdot \text { Cross } \cdot R+\beta_{6} \cdot \text { News } \cdot \text { Size }+\varepsilon^{\mathrm{a}}
\end{aligned}
$$

Panel A: Controlling for Size, Basic Regression

\begin{tabular}{lcccccc} 
& $\beta_{0}$ & $\beta_{2}$ & $\beta_{3}$ & $\beta_{4}$ & $\beta_{5}$ & $\beta_{6}$ \\
\hline slope & 0.10 & 0.02 & 0.06 & & & -0.00 \\
t-value & 7.86 & 0.80 & 1.91 & & & -1.22 \\
p-value & 0.00 & 0.21 & 0.03 & & & 0.11 \\
Nobs, Rsq & 301 & 0.06 & & & & \\
\hline
\end{tabular}

Panel B: Controlling for Size, Extended Regression

\begin{tabular}{lcccccc} 
& $\beta_{0}$ & $\beta_{2}$ & $\beta_{3}$ & $\beta_{4}$ & $\beta_{5}$ & $\beta_{6}$ \\
\hline slope & 0.10 & 0.04 & 0.03 & -0.06 & 0.09 & -0.00 \\
t-value & 7.91 & 1.27 & 0.69 & -2.37 & 1.98 & -1.21 \\
p-value & 0.00 & 0.10 & 0.25 & 0.01 & 0.02 & 0.11 \\
Nobs, Rsq & 301 & 0.08 & & & & \\
\hline \hline
\end{tabular}

${ }^{a}$ Results are from pooled time-series and cross-sectional regressions of variables of Dutch listed firms over the period 1993-2000. Firms are the constituents of the main index (AEX) and of the MidCap index. Panels A and B presents results on a test for size as an explanatory variable. $Y$ is the earnings of fiscal year before extraordinary items. $P$ is the stock price at the start of the return window. $R$ is the raw buy and hold return over a window starting a week before last year's earnings announcement and ending a week before the current earnings announcement. Returns are Winsorized: values exceeding 1 are set to 1 . News is the news dummy variable for firms with negative market adjusted performance. Cross is the dummy variable for cross listed firms. Size is the log of firm size. Size is measured as the logarithm of the market value at the end of the return window.

b,c White heteroskedasticity-consistent one-sided $t$-values, and associated p-values

d Nobs: Number of observations, Rsq: R-squares adjusted for degrees of freedom. 


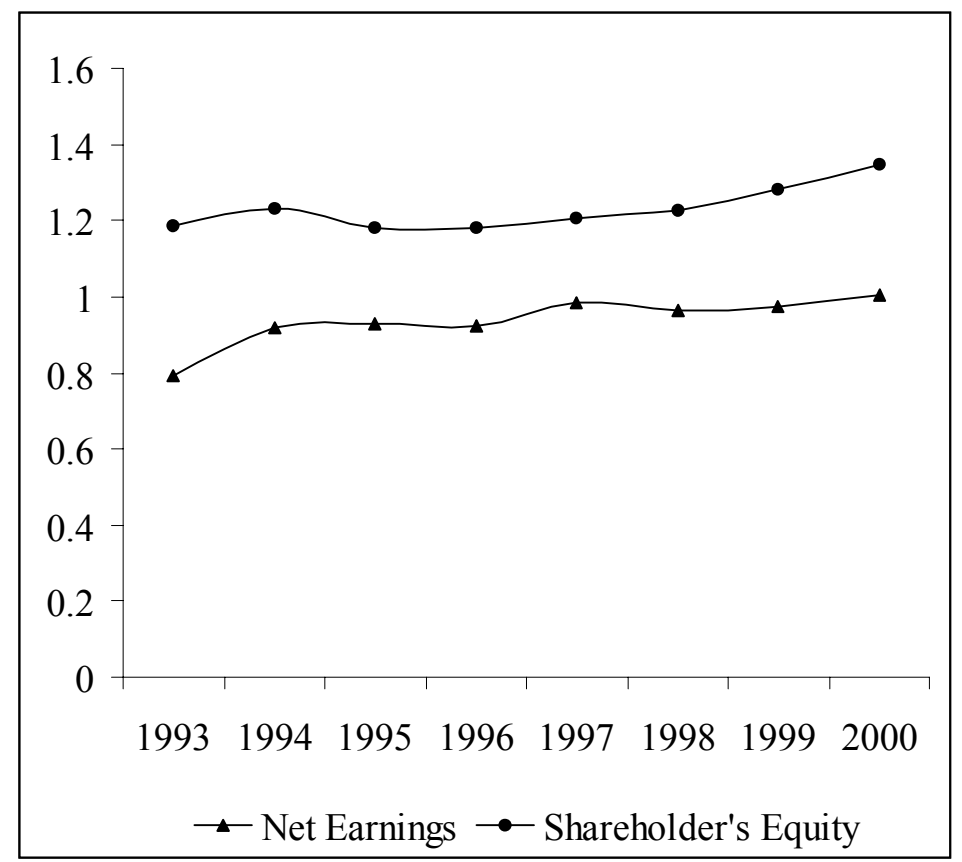

Figure 1: US GAAP figures relative to Dutch GAAP figures 